WellBeing International

WBI Studies Repository

$9-1995$

\title{
Conflict and Cooperation: Sociobiological Principles and the Behaviour of Pigs
}

\author{
David Fraser \\ Centre for Food and Animal Research \\ D. L. Kramer \\ McGill University \\ E. A. Pajor \\ Centre for Food and Animal Research \\ D. M. Weary \\ Centre for Food and Animal Research
}

Follow this and additional works at: https://www.wellbeingintlstudiesrepository.org/sociob

Part of the Animal Studies Commons, Behavior and Ethology Commons, and the Other Animal

Sciences Commons

\section{Recommended Citation}

Fraser, D., Kramer, D. L., Pajor, E. A., \& Weary, D. M. (1995). Conflict and cooperation: sociobiological principles and the behaviour of pigs. Applied Animal Behaviour Science, 44(2-4), 139-157.

This material is brought to you for free and open access by WellBeing International. It has been accepted for inclusion by an authorized administrator of the WBI Studies Repository. For more information, please contact wbisr-info@wellbeingintl.org.

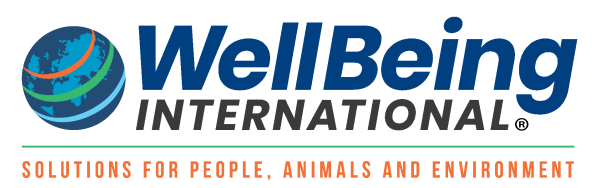




\title{
Conflict and Cooperation: Sociobiological Principles and the Behaviour of Pigs
}

\author{
David Fraser $^{1}$, D.L. Kramer ${ }^{2}$, E.A. Pajor ${ }^{1,2}$, D.M. Weary ${ }^{1}$ \\ ${ }^{1}$ Centre for Food and Animal Research \\ ${ }^{2}$ McGill University
}

\section{KEYWORDS}

behavioural ecology, sociobiology, pigs, parent-offspring conflict, maternal behaviour, parental care, lactation, sibling competition, communal nursing, dominance, aggression, resource defence, suidae

\begin{abstract}
The pig provides many examples of how principles of behavioural ecology and sociobiology can lead to insights into farm animal behaviour. According to parentoffspring conflict theory, parents should tend to give a level of parental investment somewhat below that solicited by the young. When closely confined during lactation, sows can do little to limit the amount of contact with the piglets, and the young stimulate a prolonged, high level of lactation. Certain alternative housing systems allow the sow to limit the stimulation she receives, and the resulting reduction in lactation can actually be advantageous to both parties. Communal care of offspring has both advantages and disadvantages in various species; these may help to explain why communal care occurs to a limited extent in pigs, and why sows isolate their litters in early lactation. Neonatal competition and mortality among newborn piglets have strong parallels in the "facultative siblicide" which adjusts brood size in numerous species of birds. These species typically produce slightly more young than are normally raised, and the number of siblings that survive is determined by the ability of the smaller young to withstand intense competition. The hypothesis that pigs have evolved a similar system of brood reduction may explain why piglet mortality is such an enduring problem and requires solutions different from those that work for other domestic species. Resource defence theory provides a functional framework for studies of aggressive behaviour. Factors determining the defensibility of a resource include its degree of clumping in time and space, and these suggest ways to reduce competition for food and other resources. However, aggression involved in establishing social dominance is more likely to be influenced by manipulating traits of the competing animals (competitive ability, familiarity) rather than the defensibility of resources. We conclude that principles of behavioural ecology and sociobiology provide a useful functional and evolutionary perspective to complement other approaches to the study of farm animal behaviour.
\end{abstract}




\section{Introduction}

During much of the past 20 years, the interests of farm animal ethologists and those of sociobiologists and behavioural ecologists have seemed rarely to coincide. Behavioural ecology and sociobiology have focused especially on the function of behaviour and how behaviour is affected by natural selection in relation to social and ecological conditions (see Krebs and Davies, 1991). The study of farm animal behaviour has tended to be a mixture of experimental animal psychology and classical ethology, with an emphasis on causal mechanisms of abnormal and commercially important behaviour. The choice of animals (domestic, not wild), environments (artificial, not natural) and topics (proximate cause, not function) made farm animal ethology seem largely irrelevant to more evolutionary approaches, and vice versa.

However, there is now some coming together of the fields. A desire to provide animals with more natural environments, driven by animal welfare considerations, has led to studies of farm animals in complex indoor and outdoor environments where pigs in particular show a rich repertoire of natural behaviour largely unused in confinement. There is also renewed interest in capitalizing on animals' natural behaviour for production advantages. Furthermore, a new generation of farm animal ethologists have shown greater awareness of evolutionary biology and have incorporated this thinking into their work; and behavioural ecologists are paying more attention to causal mechanisms of behaviour (Huntingford, 1993).

In the present paper we attempt to illustrate how ideas from behavioural ecology and sociobiology provide useful insights and avenues for applied behavioural research, and how domestic animals can provide excellent opportunities to test hypotheses that are often difficult to test in the wild. To do this, we will outline some basic principles and then illustrate their application to questions about domestic pigs.

\section{Basic principles}

If a behavioural trait shows heritable variation such that certain genotypic forms are more successful in reproduction, then these forms will tend to increase in proportion in future generations. In this way, natural selection can lead to the evolution of beneficial behavioural traits.

In a social context, behaviour that benefits the "individual fitness" of the performer (i.e. that individual's propensity to contribute genes to future generations) may either increase or decrease the fitness of others. On the one hand, selection can favour cooperative behaviour which increases the fitness of both the performer and the receiver. Formerly, cooperative behaviour (e.g. alarm calls, communal care of young) was often thought to have evolved for the "good of the species" (Slater, 1994), but more critical application of the principles of natural selection generally shows that cooperative behaviour more likely evolved through improved reproductive success of its performers (Williams, 1966). On the other hand, aggressive and other behaviour may improve the fitness of the performer but decrease the fitness of others, in turn creating selective pressure on others to mitigate the effect, for example by retaliating. Thus, selection can favour conflict as a natural component of social behaviour. Given the opportunities that arise for competition for scarce resources within and between species, sociobiologists have looked for and found evidence of conflict widespread in social interactions, even in the apparently cooperative interactions between parents and young (Trivers, 1974). Social behaviour thus involves both conflict and cooperation, not as simple alternatives, but as fundamental and simultaneous components of the interactions between organisms.

When the performer of some behaviour is related to the receiver, a certain proportion of their genes will be shared. If a gene benefits its bearer but has negative effects on close relatives, the result may be a net decrease in the occurrence of that gene in the next generation (Hamilton, 1964). Conversely, a gene that 
positively affects the fitness of closely related recipients should increase more than would be expected based on the benefit to its bearer alone. Thus, selection should put a brake on negative interactions and facilitate cooperative interactions when these interactions involve close relatives. The strength of this effect depends upon the degree of benefit to the performer and receiver, the number of receivers, and the closeness of their relationship to the performer (Hamilton, 1970). The "inclusive fitness" of an animal reflects the relative frequency with which its genes occur in future generations, both directly through the animal's own offspring and indirectly through its contribution to the production of offspring by relatives. Through the use of this concept, it can be shown that natural selection can favour genes that predispose animals to "altruistic" actions (i.e. those that reduce the performer's individual fitness and increase the recipient's), even to the point of death and sterility.

However, the influence of kinship on conflict is a two-edged sword. For example, when a brood of young is fed by the parents, siblings depend on the same single food source for their growth and survival; the opportunity for conflict of interest is, therefore, even greater than would normally occur among unrelated individuals. Thus, kinship creates selective pressure that should limit damaging competition among relatives, but kin also have opportunities for conflict that would not arise among non-relatives.

The application of evolutionary principles to behaviour involves several constraints and limitations. A first complication is the flexibility of behaviour. Evolutionary models sometimes treat social behaviour as if there were an allele for each alternative pattern. However, in many social situations a flexible response is

likely to be more successful than a fixed one, because the ecological situation can readily change from favouring one response to favouring another. Thus, the behavioural "traits" favoured by selection may be broad sets of conditional responses which differ in different contexts (Dominey, 1984; Gross, 1984). Secondly, behaviour arises not as the logical consequence of simple principles, but through two less predictable processes: the evolution of genotypes and the ontogeny of individuals. Given that selection works only on existing variation and random mutations, many potentially advantageous behaviour patterns may never occur for lack of a starting substrate. Thirdly, the animal's capacity to acquire and integrate the information necessary to behave adaptively may be limited. Where actions have multiple costs and benefits, determining the overall best alternative may be too difficult. In such cases animals may be selected to follow simple "rules of thumb" that are adaptive on average, but can be maladaptive in specific circumstances (Stephens and Krebs, 1986). This also applies to limited sensory capability. For example, animals may be unable to make subtle distinctions among conspecifics based on different degrees of genetic relatedness, so may distinguish merely on the basis of familiarity (Bekoff, 1981). This can result in some relatives being treated as non-relatives and vice versa. Therefore, it is important to examine the operational rules by which behaviour is caused, as well as the selection pressures underlying them.

In the following sections, we will explore how evolutionary principles apply to four main questions about the social behaviour of domestic pigs: (1) why sows do not always provide as much care as they can to their young; (2) why sows sometimes provide care to offspring not their own; (3) why newborn piglets compete so fiercely with their siblings; (4) what determines when unrelated individuals do and do not compete.

\section{Why do sows not provide as much care as they can?}

Traditionally, studies of parent-offspring relationships have focused on the care provided by the parent (Rheingold, 1963), while offspring were seen as "passive vessels into which parents pour the appropriate care" (Trivers, 1974). However, there is now ample evidence that offspring actively solicit or manipulate the parent into providing care, and that parents and offspring, who share some but not all of their genes, can be in conflict over the level of care provided. 
For many parents, the level of care given to one offspring influences the number and/or quality of other offspring (present or future) that can be raised. Trivers (1972) defined "parental investment" (as distinct from the purely descriptive term "parental care") as anything done by the parent that increases the offspring's ability to survive and reproduce while decreasing the parent's ability to invest in future offspring. For example, in many species, lactation causes a female to lose weight and subsequently have a period of reduced fertility (Altmann, 1983; Clutton-Brock et al., 1989), thus limiting future reproduction. Consequently, we expect the female to strike a balance between investing in current offspring and reserving resources to produce future offspring-a balance that should, theoretically, yield the greatest lifetime reproductive success for the parent. For the current offspring, however, the ideal balance should be the one that maximizes their own reproductive success, and this should involve relatively more parental investment in themselves, and less in future siblings who will share only a portion of their genes. Thus, the young should behave in ways that tend to manipulate the parent into providing more parental investment than is optimal for the parent.

Theoretical models show that there can be conflict between the interests of parents and offspring over the duration of parental investment ("weaning conflict") and over the level of investment throughout the period of parental care (Trivers, 1974). When the young are newly born, the fitness of both the mother and the young is best promoted if the mother gives ample food and protection so that the young will develop into reproducing adults. When the young are fully capable of independent living, the inclusive fitness of both parties is best served if the mother redirects her parental investment into producing additional offspring which will be siblings of the current offspring. Between these two extremes, a time should come when it is optimal for the parent to curtail its investment in the current young, but not yet optimal for the young that this should happen (Parker and MacNair, 1978; Lazarus and Inglis, 1986). Weaning conflict, whereby the young attempt to obtain additional investment while the mother evades or repels their attempts (Duncan et al., 1984; Leonard et al., 1988)) is seen as the most overt behavioural manifestation of parent-offspring conflict (Trivers, 1985). As more subtle tactics, parents may decrease the rate of feeding, shorten feeding episodes, or initiate fewer feedings (Altmann, 1980; Gomendio, 1991) or simply avoid their offspring (Martin, 1986; König and Markl, 1987). As counter-tactics, the offspring may increase the intensity and rate of begging through vocalizations (Davies, 1978; Stamps et al., 1985; Babbitt and Packard, 1990), and mammalian young may play an increasingly active role in initiating nursing (Horvat and Kraemer, 1982; Newberry and Wood-Gush, 1985; Martin, 1986).

Although Trivers identified a potential selection pressure, the actual occurrence of conflict over parental investment will depend on numerous factors such as the availability of food (Berger, 1979; Hauser and Fairbanks, 1988; Babbitt and Packard, 1990). When food quality is low, a mother may have to either sacrifice her infant or jeopardize her own survival and, hence, her future reproduction (Hauser, 1986). When food quality is high, a mother may be able to satisfy her own and her infant's nutritional needs with little difficulty. Under farm conditions, sows given abundant food of high quality can generally rebreed successfully immediately after or even during lactation, but if protein intake is limited, substantial loss of body condition during lactation may make the sow incapable of rebreeding for some time (King and Williams, 1984).

Interbirth interval should also influence the level of parent-offspring conflict that is expressed (Hauser and Fairbanks, 1988). If a species produces only one offspring per year, and if investment in the present young has no influence on production of young in future years, the level of investment in the present young that is optimal for the parent's fitness may be virtually the same as for the young's fitness. However, many species are capable of producing a varying number of young per unit of time. For example, vervet monkeys (Cercopithecus aethiops) produce one offspring every year or every 2 years (Hauser and Fairbanks, 1988), and wild boar (Sus scrofa) produce either one or two litters per year 
depending on food availability and the time of weaning (Mauget, 1981). For such species, we might expect parent-offspring conflict to occur especially under intermediate levels of food availability where production or non-production of additional young may depend strongly on the level of investment in the previous young.

In normal commercial housing, lactating sows are restrained in farrowing crates which make it difficult for sows to limit the amount of suckling stimulation they receive from the piglets. The amount of such stimulation appears to influence the quantity of milk provided (Barber et al., 1955; Gill and Thomson, 1956), the duration of lactation (Algers et al., 1991) and to depress maternal fertility (Foxcroft, 1990). In "get-away" farrowing pens where sows can leave the piglets at will by stepping over a piglet-proof barrier, many sows decrease the proportion of time spent with the young, starting in the second week of lactation (Bee, 1991; Rantzer, 1993; Pajor et al., 1994). Compared to confined sows, these sows effect a greater reduction in milk production, lose less weight during lactation, and tend to return to oestrus more promptly (Pajor et al., 1994). All these are consistent with parent-offspring conflict theory.

Giving the sow more control over parental investment may have other benefits. In conventional farrowing crates, sows increasingly lie with the udder inaccessible to the piglets, especially after the third week of lactation (De Passille and Robert, 1989), and sows in crates show increased plasma cortisol levels, an indicator of "stress", after 4 weeks of lactation compared to sows housed in pens which permit more freedom of movement (Cronin et al., 1991). These observations suggest that stress may be reduced by allowing the sow to limit the level of contact with the litter as lactation advances. Furthermore, although the piglets of confined sows initially benefit from the large amount of milk they obtain, they experience a drastic change when weaned abruptly at 3-5 weeks of age. With sows in get-away pens, as milk production declines, offspring generally begin eating more solid food as long as diet quality is high enough, and they are better prepared for abrupt weaning (Pajor et al., 1994). Thus, compared to typical commercial practice, which biases parent-offspring conflict strongly in favour of the young, allowing sows some control over the level of parental investment can actually have advantages for both sow and litter under the right management conditions.

\section{Why do sows sometimes provide care to offspring not their own?}

Wild Sus scrofa typically live in groups of two to five related females and their immature offspring (Graves, 1984; Dardaillon, 1988). Like her wild counterpart, a pregnant domestic sow housed outdoors usually leaves the group a day or two before farrowing, finds and modifies a suitable nest site, and rejoins the group with her litter when the young are about 10 days old (Dardaillon, 1988; Jensen, 1986). Rejoining the group exposes the sow to attempts by other piglets to suckle. Sows seem tolerant of this "theft" of milk (domestic pigs: Newberry and Wood-Gush, 1985; wild pigs: Eisenberg and Lockhart, 1972) to the extent that a sow's own piglets may occasionally die after being displaced from the udder by piglets from another litter (Newberry and Wood-Gush, 1985). Similar "cross-suckling" also occurs when unweaned domestic pigs are grouped at 3 weeks of age in multi-litter pens (Bryant and Rowlinson, 1984). The pig is thus one of a large group of mammals, birds, fishes and insects that provide some degree of care to nondescendant young of the same species (see Stacey and Koenig, 1990; Wisenden and Keenleyside, 1992; Trumbo and Wilson, 1993; Jennions and Macdonald, 1994).

Since care of young is often costly in time, effort and nutrients, it is surprising to find individuals providing care to young that are not their own. Several evolutionary explanations have been proposed. First, for individuals unable to breed, caring for the young of relatives may provide an alternative means to increase inclusive fitness (Emlen, 1991). For example, an individual that cannot obtain a breeding territory may gain indirect fitness by assisting its parents in the care of younger siblings, or by adopting the offspring of a relative that has died. 
Second, even for individuals raising offspring of their own, the inclusive fitness benefits of caring for other offspring may outweigh the costs. This is most likely if the benefitting young are closely related, if many young can benefit from a single act (as in alarm calling or driving off a predator), if the care greatly increases the young's fitness (as in adoption after death of the parent), and if the type of care is low in cost to the provider (as in vigilance for predators: Sherman, 1980; Eadie et al., 1988). Even provision of milk could be relatively low in cost if food is abundant and, owing to offspring age or number, a mother can provide more milk than her own young can consume. The caregiver's own young may also benefit from adoption of additional young through improved thermoregulation or through lowered risk of predation by improved defence or by diluting the impact of predators (e.g. Wisenden and Keenleyside, 1992). In domestic mice (Mus musculus) and rats (Rattus norvegicus), offspring may have greater growth rate and/or survival in combined litters, even when the ratio of mothers to young remains constant (Sayler and Salmon, 1969, 1971; Menella et al., 1990; Kijnig 1993,1994), perhaps in part because of increased stimulation of the mothers by the large number of young (Sayler and Salmon, 1971).

As a third possible evolutionary explanation, parents caring for non-descendant young may simply be making the best of a bad situation. For example, if a snow goose (Anser caerulescens) lays an egg near a nest not her own, the nest owner will often "adopt" the egg by rolling it into her nest. This behaviour appears to lower slightly the fitness of the adopting parent, but leaving the egg outside the nest attracts predators and could be disastrous (Lank et al., 1991). Lions (Panthera leo) frequently nurse nondescendant young. Pusey and Packer (1994) argue that females with litters aggregate as a way to defend the young against infanticide, and that nursing of non-descendant young is impractical to avoid under these circumstances.

Finally, caring for the offspring of others may actually be non-adaptive behaviour where the receiver benefits at the expense of the provider. This is presumably the case with parasitic cuckoo nestlings (Cuculus canorus) cared for by their adult hosts even after all the adult's own young have been eliminated from the nest (Davies, 1992). Such non-adaptive behaviour may occur because the host lacks an adequate mechanism to recognize its own young.

A number of these arguments suggest a general hypothesis for communal care in pigs. Since the stable social group of wild and feral pigs consists of related females and their offspring (Mauget, 1981; Graves, 1984), sharing of milk with needy piglets from other litters may contribute to the inclusive fitness of the donors. However, the principal advantages of communal rearing may lie in other benefits of grouping such as thermoregulation or improved defence of the young (Mauget, 1981; Graves, 1984; see also Packard et al., 1990, on collared peccaries, Tuyassu tajacu), and some suckling by non-offspring may be an acceptable price to pay for this advantage. For a mother that typically nurses multiple young while lying on her side, the disruption to her own young of trying to detect and avoid milk theft may simply outweigh the cost of the lost milk. The sow's protection against excessive cross-suckling may, therefore, hinge on the isolation immediately after farrowing which allows her own young to become established on their respective teats, and gives the unused teats time to begin regressing and thus become less attractive to other young. The synchronization of reproduction in groups of sows (Mauget, 1981; Delcroix et al., 1990) may also help to reduce harmful effects of competition from older litters (see Menella et al., 1990).

Given that the sow isolates her newborn litter, the farrowing sow should not need, and appears not to possess, a means of detecting and rejecting newborns that are not her own. Farrowing sows are so tolerant of other young that fostered piglets are often raised as successfully as the sow's own offspring if fostering is done early enough (Fraser et al., 1979). After a few days of lactation, the sow does appear to detect and reject foreign piglets, and piglets fostered at this stage have less success in becoming established (Horrell and Bennett, 1981). However, most still survive, suggesting that, with communal 
rearing, a needy and persistent piglet might well be kept alive by an aunt or grandmother. This relative tolerance of other young allows some extreme fostering practices, such as using a high-producing sow to rear a litter of small foster piglets after her own young have been removed for weaning.

\section{Why do newborn piglets compete so fiercely with their siblings?}

A sow nursing her litter of piglets is such a picture of peace and fecundity that it was often used as a decorative motif in medieval churches. In reality, domestic piglets fight vigorously with their litter-mates for access to the sow's teats during the first hours after birth, and this competition plays a major role in neonatal deaths (Hartsock and Graves, 1976). Such intense neonatal competition is unusual among mammals, but even more remarkable is the pig's unique dentition (see below) which allows the newborn to wound the faces of its litter-mates during disputes over teats.

Why has the pig evolved such intense neonatal competition? An explanation is suggested by the work of Mock (1984) on avian siblicide (see Fraser, 1990). In certain species of birds, sibling competition plays a key role in reproduction. For example, great egrets (Casmerodius albus) commonly lay slightly more eggs than the number of chicks that are normally reared. Because incubation begins as soon as the first egg is laid, the young hatch over a period of several days. This gives each chick a head start in growth over its younger siblings. The chicks are so aggressive that the last to hatch may be killed outright or may die of starvation because of fierce competition for food (Mock, 1987). However, even the youngest may be raised successfully if food proves to be particularly abundant or if one of the larger chicks should die. The small cost of producing an extra chick thus provides an "insurance policy" on the life of the older siblings, and it creates the option of raising additional young should the food supply prove to be adequate. Mock (1984) refers to this system, where the smallest chicks may or may not survive, as "facultative siblicide", in contrast to "obligate siblicide" in species like the black eagle (Aquila verreauxi), where the parents never raise more than one offspring in a season, and the second chick is invariably killed if the first survives.

This use of sibling competition in avian reproduction involves three components: (1) a small extra investment to produce one or more "spare" young; (2) intense sibling competition which ultimately determines the number of young that will be raised; (3) a size difference which produces a competitive asymmetry and ensures that the well-being of the more advantaged young will not be jeopardized by competition from the "spares" (Mock, 1984). Pigs fit this pattern remarkably well (Fraser, 1990; see also Forbes, 1990). First, the cost to the sow of producing one or two extra offspring is extremely small, as the lightest piglet often weighs less than $1 \%$ of the mother's body weight. Second, piglet mortality statistics indicate that, in the absence of special management, the loss of one or two piglets from a litter is more the norm than the exception, and neonatal competition is a major factor in these deaths (English and Smith, 1975). Third, many litters of piglets do show a remarkable variability in birth weights, with the smallest piglet often only half or even one-third the weight of the heaviest. Furthermore, when the birth weights of a litter depart from a statistically normal distribution, this is almost invariably because of one or more unusually small piglets, not unusually large ones (Van der Lende and De Jager, 1991).

As a means of adjusting litter size, neonatal piglet competition functions with deadly efficiency. Piglets that fail to establish adequate access to a teat usually die during the first day or two (English and Smith, 1975), without depriving the rest of the litter of any substantial amount of milk. The high level of neonatal competition ensures that piglets of low birth weight, or that are jeopardized in other ways, are by far the most likely casualties (English and Smith, 1975). Hastening their demise is the tendency of malnourished piglets to stay near the udder where they are especially likely to be crushed when the sow changes posture (Weary et al., unpublished results). Furthermore, if the sow has a poor milk supply, competitive 
jostling at the udder continues longer than normal and more piglets are likely to succumb (De Passille and Rushen, 1989).

A slight overproduction of young may increase fitness in the pig in various ways. Given that gestation lasts nearly 4 months, the availability of food during lactation may be unpredictable at the time of conception (Algers, 1989), so the sow may help to maximize the number of young raised by producing extra young that can be discarded soon after birth if they cannot be reared. However, piglets that are not sufficiently competitive to establish ownership of a teat will sometimes survive as runts by suckling other teats opportunistically (De Passille et al., 1988), and these animals may be well positioned to take over a functioning teat if a litter-mate should die. Runts that learn to suckle opportunistically may also be particularly well suited to exploit another sow in communally nursed litters.

Our hypothesis--that pigs are adapted to overproduce young of unequal birth weight and allow sibling competition to determine the ultimate litter size--is admittedly speculative. In pigs, artificial selection has apparently led to increases in litter size, in the number of teats, and in the sow's milk production; presumably this has altered the level of competition and perhaps the degree of asymmetry of birth weights, Hence, the hypothesis needs to be tested with data from wild pigs, but the fact that various wild species of pigs also possess specialized dental weaponry at birth (see Fraser and Thompson, 1991) suggests that neonatal rivalry played a role in the evolution of the group. The hypothesis also puts the practical problem of piglet deaths in a different light. It implies that when we try to keep large litters alive, we are battling not just against disease, harsh weather and other external challenges, but against an evolved reproductive strategy of the species. To promote neonatal survival under these circumstances, we need to detect or predict litters where piglets are competing unsuccessfully and reduce the competitive pressure by fostering piglets to a different sow or by providing alternative food sources.

The neonatal dentition of the pig makes the species almost unique among mammals in having a form of weaponry that is used principally against siblings (see also O'Gara, 1969; Frank et al., 1991). The piglet is born with the four deciduous canines and four deciduous third incisors fully erupted at birth and angling slightly outward from the jaw. Furthermore, the anterior portion of the jaw is rotated at birth such that the third incisor temporarily assumes a canine-like orientation, thus giving the piglet eight canine-like teeth which can deliver a damaging sideward bite to the faces of litter-mates during competition for teats. Fraser and Thompson (1991) have argued that this weaponry likely evolved through an evolutionary arms race (Dawkins and Krebs, 1979) driven by sibling competition. However, we would expect the evolution of the teeth to represent a delicate balance, promoting individual fitness by allowing the weapon-holder to secure adequate resources for growth and survival, while not causing so much damage to litter-mates that inclusive fitness would be unduly diminished. Experimental evidence is consistent with this view. In litters of six to ten piglets, the presence of intact teeth confers little advantage over litter-mates whose teeth have been clipped. Only in large litters of about 12 piglets, where some deaths are the norm, do intact teeth give their bearers a substantial advantage in survival and weight gain compared to littermates without teeth (Fraser and Thompson, 1991).

The mating habits of the pig may also contribute to its system of armed sibling rivalry. An arms race among litter-mates would be more likely to evolve in litters of mixed paternity, where well-armed offspring sired by one male could have a distinct advantage over poorly armed litter-mates sired by another, than in litters of full siblings where higher genetic relatedness would put a greater brake on damaging competition. Several lines of evidence suggest that litters of mixed paternity could have played a role in the evolution of pigs (see Fraser and Thompson, 1991). First, domestic sows have a relatively long oestrus period of 2-3 days; they readily mate with different males, and resulting litters of mixed paternity are common (Sumption et al., 1959; Martin and Dziuk, 1977). Second, the limited literature on the mating behaviour of wild pigs gives little evidence of pigs using the common ungulate mechanisms (harem 
formation, postcoital guarding by the male, non-receptivity by the female after a single mating) that might help to ensure litters of single paternity. Third, the boar has an unusually large semen volume (typically $250 \mathrm{ml}$ per ejaculation, compared to about $1 \mathrm{ml}$ for sheep, $4 \mathrm{ml}$ for cattle, and $70 \mathrm{ml}$ for horses; Hansel and McEntee, 1970) which could be interpreted as an adaptation to sperm competition following the arguments of Harcourt et al. (1981).

\section{What determines whether unrelated individuals compete?}

Although animals compete fiercely at certain times, they refrain from competition at others. What factors determine whether competition or more peaceful cohabitation will prevail?

Apart from sibling competition, much of the overt aggression seen with domestic pigs occurs in two situations: a brief "acute" period of fighting when unfamiliar pigs are brought together, and the longer-term "chronic" competition that occurs over food and other resources (Fraser, 1984). The acute conflict occurs quite predictably within the first hour of bringing unacquainted animals together. It usually involves vigorous fighting and great exertion, and it does not appear to centre on any immediate competition for resources. The chronic conflict occurs less predictably. It tends to consist of briefer threats, bites and butts that only occasionally escalate into more prolonged fights, and it often involves competition for an identifiable resource.

In the past, aggressive behaviour of pigs has often been interpreted in terms of dominance hierarchies (e.g. Ewbank, 1976). Roughly speaking, pigs fight with unfamiliar animals to establish dominance, and they no longer fight once dominance has been settled. This hypothesis is a useful first approximation, but it leaves a great deal of complexity unexplained. For example: some groups show continued and fluctuating levels of fighting (Meese and Ewbank, 1972) ; retaliation by less dominant animals is common in established groups (Bryant and Ewbank, 1972; Baxter, 1985) some sows, although of very low rank according to dominance measures, appear to thrive by avoiding conflict (Mendl et al., 1992). Some of this variation may be explained by putting dominance and aggression in a behavioural ecological and sociobiological context.

Since Brown (1964) introduced an economic perspective on resource defence, behavioural ecologists have looked to factors affecting the "defensibility" of resources in trying to understand and predict when animals will compete aggressively (see Warner, 1980; Grant, 1993). Some of the important environmental factors influencing defensibility are the clumping of resources in space and in time, the predictability of their arrival in space and time, and the number of potential competitors present. The clumping in space of a resource will affect its defensibility (Grant and Guha, 1993)) because a resource that is concentrated in one place can be more easily monopolized by a single individual than a resource that is widely dispersed. Clumping in time can also be important. When many resource items become available at the same time they become uneconomical to defend because handling one unit makes it difficult to defend other units from competitors; if the same amount of resource arrives in a more asynchronous way, then one individual might better defend and exploit each unit as it arrives (Grant and Kramer, 1992). The predictability of a resource affects its defensibility, because with a predictable resource animals can more effectively establish control of the area before the resource arrives (Grand and Grant, 1994). Finally, the number of potential competitors affects defensibility because a high rate of attempted intrusions dilutes the effectiveness of aggression and increases its costs. Many species which are very aggressive at low density are much less so at high density (e.g. Marzluff and Heinrich, 1991; Jones, 1983; M. Chapman and D.L. Kramer, unpublished results).

Environmental features which increase the defensibility of a resource should result in its being used disproportionately by a certain fraction of the individuals present. Whether this involves increased 
aggression depends on how the other individuals respond to those defending the resource. If other members of the group are unlikely to succeed in obtaining the resource, or if the amount they could gain is likely to be of little benefit, they should avoid conflict rather than challenge the defender. This will result in uneven distribution of the resource combined with low apparent aggression. However, if there is insufficient space for avoidance, the defender may continue to attack subordinates. In such circumstances, changing the environment to make resources less defensible (e.g. by increasing the number of competitors or spreading out the resource) may help reduce uneven use of the resource and associated aggression. Intermediate between these states is the situation of moderate monopolization and high aggression when both defenders and intruders have a chance at success and the conflict remains unresolved. Thus, in many confined and wild animals, total rates of aggression are highest at intermediate densities: at lower densities, some group members avoid the resource defenders and miss out on resources; at high densities, the number of challengers overwhelms and suppresses attempts at resource defence (e.g. Keenleyside and Yamamoto, 1962; M. Chapman and D.L. Kramer, unpublished results).

These principles suggest many options for reducing aggressive competition over resources, some of which have been used in providing food to pigs. If feed is distributed over a large area of floor, aggressive competition is reduced compared to providing feed in a more clumped manner in a trough (Kennerley and Lean, 1983). As a variation of this procedure, scattering large pellets over an area of straw bedding can make food particularly difficult to defend and provides a means to reduce competition for feed even among pregnant sows on restricted intakes. Reduced aggression by less clumping of resources can also be achieved by using several feeders rather than one (Hansen et al., 1982), or by physical barriers between feeders which can make it difficult for an individual to defend more than one location (Baxter, 1985).

Variations in temporal clumping also show promise. One option is to provide the resource as synchronously as possible. Automated systems that simultaneously drop food over a substantial area can help to keep competition at low levels among group-housed sows (Csermely and Wood-Gush, 1986). By providing food to all individuals at the same time, one sow cannot attempt to dislodge another from her feed until she has finished consuming her own. An extreme application of synchronous feeding is the "skip-a-day" system sometimes used for sows housed outdoors with ample opportunity to forage. In this system, enough concentrated feed for 2 days is provided simultaneously to all sows every second day in order to eliminate competition. In an alternative approach, called the "bio-fix" dry sow feeding system, food is delivered to the feeders at low rate-less than the potential rate of intake-for an extended time. In order to compete with other sows, a sow must leave her own feeder and thus potentially lose the feed that comes to it while she is away. Thus, it pays sows to stay at their own feeders and not compete with one another.

Manipulating group size provides possible avenues to reduce competition. Traditionally it has been thought that group size for pigs should be limited in order to control aggression. However, practical experience suggests that very large groups of sows (Brade, 1988) or growing pigs (Nehring, 1981) can be housed together with minimal aggression if the environment is sufficiently complex. More needs to be known about how competition and aggression among pigs change over a wide range of group sizes.

Attempts have been made to use environmental manipulations (space, straw, and ad libitum feed) to reduce the acute aggression between newly mixed pigs, but such attempts have met with only limited success (e.g. Kelley et al., 1980; McGlone, 1986; Barnett et al., 1994). We suggest that this form of aggression needs to be addressed using a different set of principles. Selection can be expected to favour some sharing of resources with related animals, whereas we expect little or no advantage from sharing with non-relatives. Since the natural social group of wild pigs generally consists of several related females 
and their offspring, with mature males living apart from the group (Dardaillon, 1988)) familiar animals are likely to be relatives, and unfamiliar animals not. Rather than making subtle distinctions based on degree of relatedness, pigs may simply use the rule of thumb that familiar animals are to be tolerated more than unfamiliar. Hence, when pigs attack a new animal introduced into a group, they may be following a basic inclination to behave intolerantly toward strangers. Some reduction in fighting has been reported by making pigs familiar with each other when actual fighting was impossible owing to physical barriers (Fraser, 1974) or sedation (Symoens and Van den Brande, 1969). Even among relatives, however, we expect there to be an advantage to one animal to establish a dominant position over other group members such that future access to any disputed resources is made easier. Hence, familiarity alone should be insufficient to eliminate fighting; actual establishment of dominance should also be important. Rushen (1988) gave weaner pigs an opportunity to become familiar with each other, but found no resulting reduction in fighting until dominance had been established.

Individuals benefit from aggressive competition only if they win. If an animal is going to lose a contest it is better off to avoid it, and hence also avoid the potentially high costs associated with fighting (i.e. time, energy, and risk of injury or death). Therefore, two animals that are evenly matched in size, weapons, and skill are more likely to fight than pairs of animals so unevenly matched that the weaker has little chance of winning (Parker, 1974). When pigs of very different sizes are mixed, there tends to be less fighting than when more evenly matched individuals are mixed (Rushen, 1987, 1988; but see Tindsley and Lean, 1984). This reduction in fighting probably occurs because the dominant animals are less often challenged when the likely outcome is clear. In groups of uneven size, smaller animals may show inferior weight gain, perhaps because they are partially excluded from resources (e.g. Moore et al., 1994)) but this might be overcome if food were provided in ways that reduce competition.

In short, both theory and empirical evidence suggest that more application of resource defence theory could help in controlling aggression as well as the competition for resources that underlies it. While many of the principles seem intuitively obvious, they are often violated in practice, as in the use of a single, regular feeding site in a defensible structure.

\section{Concluding remarks}

Thus far, we have emphasized the usefulness of sociobiology and behavioural ecology in understanding the social behaviour of pigs, but the flow of ideas can be in both directions. As we have described, pigs have numerous traits that make them interesting subjects for studying basic principles of social behaviour. In addition to weaning conflict, social care of young, neonatal competition, and resource defence (as described above), pigs also have unusually complex nursing and suckling behaviour (Fraser, 1980)) numerous forms of aggression (Jensen, 1980; Rushen and Pajor, 1987)) a subtle type of withinlitter competition that persists throughout lactation (Fraser, 1990), and a rich repertoire of vocal communication (Grauvogl, 1958; Algers and Jensen, 1985). The species thus provides opportunities to study a host of sociobiological phenomena, while the tractability of domestic pigs allows growth and reproductive success to be monitored, together with experimental control over level of nutrition, degree of competition for resources, and other variables that present much greater difficulties in field studies.

The perspective of behavioural ecology and sociobiology has typically looked to the fitness costs and benefits of alternative behaviours as a source of insight and hypotheses. Fitness, which is difficult to quantify at the best of times, requires some reinterpretation for farm or other captive environments. In these systems, fitness cannot be construed as an animal's actual contribution to future generations, as breeding is usually controlled by humans pursuing economic and other goals. Rather, we must use proximate correlates of fitness, such as indications that the animal would be capable of reproducing well in a natural environment. In some cases, assessing fitness costs and benefits is straightforward, as when 
animals die before reaching the age of reproduction; in other cases, applying fitness concepts requires educated guesses about the environments in which the species evolved.

Applying fitness concepts to animals genetically altered by domestication involves some further complexity. Studies under seminatural conditions show that domestic pigs retain a large amount of their phylogenetic heritage (e.g. Jensen, 1986). This is to be expected, as behavioural traits tend to be very stable under domestication (Hale, 1969) and most domestic animals continue to be subject to a form of "natural" selection that favours the maintenance of good behavioural functioning. Furthermore, given that many evolved traits of mammalian social behaviour are broad sets of conditional responses rather than fixed ones, they will often be involved in, not irrelevant to, the animals' behaviour under artificial conditions. Nonetheless, artificial selection has clearly modified some of the products of natural selection. For example, domestic sows have larger litters, more teats, and presumably greater milk production than wild ones. Hence, the degree and consequences of sibling rivalry may be quite different in domestic compared to wild pigs. The quantity and quality of food available to farm animals is presumably different and more predictable than in the wild; hence, the degree of resource defence and parent-offspring conflict may be altered. Therefore, a thoughtful approach is needed in using domestic pigs to test ideas derived from evolutionary theory.

Ethology has traditionally sought to answer the "four questions" about animal behaviour outlined by Tinbergen (1963): How is behaviour caused? How does it develop? How did it evolve? What is its adaptive function? Behavioural ecology and sociobiology tend to concentrate on adaptive function within an evolutionary context (Dawkins, 1989). We have argued that this approach generates valuable insights and hypotheses, and reminds us to look for the continued influence of natural selection in artificial systems. However, for practical purposes of farm animal management and welfare, questions of ontogeny and immediate causation are often more critical. Hence, the approach of behavioural ecology and sociobiology should be seen as complementing, and by no means replacing, more traditional approaches to farm animal behaviour.

\section{Acknowledgements}

The Montreal Inter-University Behavioral Ecology Discussion Group and numerous colleagues in Ottawa and Montreal provided valuable comments and assistance with this paper. Our research in these areas was supported by the Natural Sciences and Engineering Research Council of Canada, Agriculture and Agri-Food Canada, and Manitoba Pork.

\section{References}

Algers, B., 1989. Vocal and tactile communication during suckling in pigs. Swedish University of Agricultural Sciences, Skara, Report 25.

Algers, B. and Jensen, P., 1985. Communication during suckling in the domestic pig. Effects of continuous noise. Appl. Anim. Behav. Sci., 14: 49-61.

Algers, B., Madej, S., Rojanasthien, S. and Uvnas-Moberg, K., 1991. Quantitative relationships between suckling-induced teat stimulation and the release of prolactin, gastrin, somatostatin, insulin, glucagon and vasoactive intestinal polypeptide in sows. Vet. Res. Commun., 35: 395-407. 
Aitmann, J., 1980. Baboon Mothers and Infants. Harvard University Press, Cambridge.

Altmann, J., 1983. Costs of reproductionin baboons (Papio cynocephalus). In: W. Aspey and S. Lustick (Editors), Behavioural Energetics: The Cost of Survival in Vertebrates. Ohio State University Press, Columbus, pp. 67-88.

Anonymous, 1913. Roman Farm Management. The Treatises of Cato and Vatro, done into English, with Notes of Modem Instances, by a Virginia Farmer. Macmillan, New York.

Babbitt, K.J. and Packard, J.M., 1990. Parent-offspring conflict relative to phase of lactation. Anim. Behav., 40: 165-113.

Barber, R.S., Braude, R. and Mitchell, K.G., 1955. Studies on milk production of Large White pigs. J. Agric. Sci., 46: 97-118.

Bamett, J.L., Cronin, G.M., McCallum, T.H. and Newman, E.A., 1994. Effects of food and time of day on aggression when grouping unfamiliar adult pigs. Appl. Anim. Behav. Sci., 39: 339-347.

Baxter, M., 1985. Social space requirements of pigs. In: R. Zayan (Editor), Social Space for Domestic Animals. Martinus Nijhoff, Dordrecht, pp. 116-127.

Bekoff, M., 1981. Mammalian sibling interactions: genes, facilitative environments, and the coefficient of familiarity. In: D.J. Gubemick and P.H. Klopfer (Editors), Parental Care in Mammals. Plenum Press, New York, pp. 307-346.

Berger, J., 1979. Weaning conflict in desert and mountain bighorn sheep (Ovis Canadensis) ecological interpretation. Z. Tierpsychol., 50: 188-200.

Bee, K., 1991. The process of weaning in pigs: when the sow decides. Appl. Anim. Behav. Sci., 30: 4759.

Brade, M., 1988. Electronic sow feeders are here to stay. Pigs, 4: 1-5.

Brown, J.L., 1964. The evolution of diversity in avian territorial systems. Wilson Bull., 76: 160-169.

Bryant, M.J. and Ewbank, R., 1972. Some effects of stocking rate and group size upon agonistic behaviour in groups of growing pigs. Br. Vet. J., 128: 64-70.

Bryant, M.J. and Rowlinson, P., 1984. Nursing and suckling behaviour of sows and their litters before and after grouping in multi-accommodation pens. Anim. Prod., 38: 277-282.

Clutton-Brock, T.H., Albon, SD. and Guinness, F.E., 1989. Fitness costs of gestation and lactation in wild mammals. Nature, 337: 260-262.

Cronin, G.M., Barnett, J.L., Hodge, F.M., Smith, J.A. and McCallum, T.H., 1991. The welfare of pigs in two farrowing/lactation environments: cortisol responses of sows. Appl. Anim. Behav. Sci., 32: 117-127.

Csermely, D. and Wood-Gush, D.G.M., 1986. Agonistic behaviour in grouped sows. I. The influence of feeding. Biol. Behav., 11: 244-252.

Dardaillon, M., 1988. Wild boar social groupings and their seasonal changes in the Carmargue, Southern France. Z. Saugetierkd., 53: 22-30. 
Davies, N.B., 1978. Parental meanness and offspring independence: an experiment with hand-reared great tits Parus major. Ibis, 120: 508-514.

Davies, N.B., 1992. Dunnock Behaviour and Social Evolution. Oxford University Press, Oxford.

Dawkins, MS., 1989. The future of ethology: how many legs are we standing on? In: P.P.G. Bateson and P.H. Klopfer (Editors), Perspectives in Ethology. Plenum Press, New York, pp. 47-54.

Dawkins, R. and Krebs, J.R., 1979. Arms races between and within species. Proc. R. Sot. Lond., 205: 489-511.

Delcroix, I., Mauget, R. and Signoret, J.P., 1990. Existence of synchronization of reproduction at the level of the social group of the European wild boar (Sus scrofa). J. Reprod. Fertil., 89: 613-617.

De Passille, A.M.B. and Robert, S., 1989. Behaviour of lactating sows: influence of stage of lactation and husbandry practices at weaning. Appl. Anim. Behav. Sci., 23: 315-329.

De Passille, A.M.B. and Rushen, J., 1989. Using early suckling behavior and weight gain to identify piglets at risk. Can. J. Anim. Sci., 69: 535-544.

De Passille, A.M.B., Rushen, J. and Hartsock, T.G., 1988. Ontogeny of teat fidelity in pigs and its relation to competition at suckling. Can. J. Anim. Sci., 68: 325-338.

Dominey, W.J., 1984. Alternative mating tactics and evolutionarily stable strategies. Am. Zool., 24: 385396.

Duncan, P., Harvey, P.H. and Wells, S.M., 1984. On lactation and associated behaviour in a natural herd of horses. Anim. Behav., 32: 255-263.

Eadie, J.M., Kehoe, F.P. and Nudds, T.D., 1988. Pre-hatch and post-hatch brood amalgamation in North American Anatidae: a review of hypotheses. Can. J. Zool., 66: 1709-1721.

Eisenberg, J.F. and Lockhart, M., 1972. An Ecological Reconnaissance of Wilpattu National Park, Ceylon. Smithsonian Contributions to Zoology No. 101, Smithsonian Institution Press, Washington.

Emlen, LT., 1991. Evolution of cooperative breeding in birds and mammals. In: J.R. Krebs and N.B. Davies (Editors), Behavioural Ecology, an Evolutionary Approach, 3rd edn. Blackwell Scientific, Oxford, pp. 301-337.

English, P.R. and Smith, W.J., 1975. Some causes of death in neonatal piglets. Vet. Ann., 15: 95-104.

Ewbank, R., 1976. Social hierarchy in suckling and fattening pigs: a review. Livest. Prod. Sci., 3: 363-372.

Forbes, LX, 1990. Insurance offspring and the evolution of avian clutch size. J. Theor. Biol., 147: 345359.

Foxcroft, G., 1990. Management of the lactating and weaned sow. In: Advances in Pork Production, University of Alberta Press, Edmonton, pp. 219-234.

Frank, L.C., Glickman, S.E. and Light, P., 1991. Fatal sibling aggression, precocial development, and androgens in neonatal spotted hyenas. Science, 252: 702-704. 
Fraser, D., 1974. The behaviour of growing pigs during experimental social encounters. J. Agric. Sci., 82: 147-163.

Fraser, D., 1980. A review of the behavioural mechanism of milk ejection of the domestic pig. Appl. Anim. Ethel., 6: 247-255.

Fraser, D., 1984. The role of behavior in swine production: A review of research. Appl. Anim. Ethol., 11: 317-339.

Fraser, D., 1990. Behavioural perspectives on piglet survival. J. Reprod. Fertil., Suppl., 40: 355-370.

Fraser, D. and Thompson, B.K., 1991. Armed sibling rivalry among suckling piglets. Behav. Ecol. Sociobiol., 29: 9-15.

Fraser, D., Thompson, B.K., Ferguson, D.K. and Darroch, R.L., 1979. The "teat order" of suckling pigs. III. Relation to competition within litters. J. Agric. Sci., 92: 257-261.

Gill, J.C. and Thomson, W., 1956. Observations on the behaviour of suckling pigs. Br. J. Anim. Behav., 4: 46- 51.

Gomendio, M., 1991. Parent/offspring conflict and maternal investment in rhesus macaques. Anim. Behav.. 42: 993-1005.

Grand, T.C. and Grant, J.W.A., 1994. Spatial predictability of food influences its monopolization and defence by juvenile convict cichlids. Anim. Behav., 47: 91-100.

Grant, J.W.A., 1993. Whether or not to defend? The influence of resource distribution. Mar. Behav. Physiol., 23: 137-153.

Grant, J.W.A. and Guha, R.T., 1993. Spatial clumping of food increases its monopolization and defense by convict cichlids, Cichlasoma nigrofascitum. Behav. Ecol., 4: 293-296.

Grant, J.W.A. and Kramer, D.L., 1992. Clumping of food arrival reduces its monopolization and defence by zebrafish, Brachydanio rerio. Anim. Behav., 44: 101-110.

Grauvogl, A., 1958. Uber das Verhalten des Hausschweines unter besondeter Berticksichtigung des Fortpflanzungsverhaltens. Inaugural Dissertation, Freien Universitit Berlin.

Graves, H.B., 1984. Behavior and ecology of wild and feral swine (Sus scrofa). J. Anim. Sci., 58: 482-492.

Gross, M.R., 1984. Sunfish, salmon, and the evolution of alternative reproductive strategies and tactics in fishes. In: R.I. Wootton (Editor), Fish Reproduction: Strategies and Tactics. Academic Press, London, pp. 55-75.

Hale, E.B., 1969. Domestication and the evolution of behaviour. In: E.S.E. Hafez (Editor), The Behaviour of Domestic Animals, 2nd edn. Bailhere, Tindall \& Cassell, London, pp. 2242.

Hamilton, W.D., 1964. The genetical evolution of social behaviour. J. Theor. Biol., 7: 1-52.

Hamilton, W.D., 1970. Selfish and spiteful behaviour in an evolutionary model. Nature, 228: 1218-1220.

Hansel. W. and McEntee, K., 1970. Male reproductive processes. In: M.J. Swenson (Editor), Dukes' Physiology of Domestic Animals, 8th edn. Cornell University Press, Ithaca, pp. 1298-1338. 
Hansen, L.L., Hagelso, A.M. and Madsen, A., 1982. Behavioural results and performance of bacon pigs fed "ad libitum" from one or several self-feeders. Appl. Anim. Ethel., 8: 307-333.

Harcourt, A.H., Harvey, P.H., Larson, S.G. and Short, R.V., 1981. Testis weight, body weight and breeding system in primates. Nature, 293: 55-57.

Hartsock, T.G. and Graves, H.B., 1976. Neonatal behavior and nutrition-related mortality in domestic swine. J. Anim. Sci., 42: 235-241.

Hauser, M.D., 1986. Parent-offspring conflict: care-elicitation behaviour and the "cry-wolf' syndrome. In: J.G. Else and PC. Lee (Editors), Primate Ontogeny, Cognition and Social Behaviour. Cambridge University press, Cambridge, pp. 193-203.

Hauser, M.D. and Fairbanks, L.A., 1988. Mother-offspring conflict in vervet monkeys: variation in response to ecological conditions. Anim. Behav., 36: 802-813.

Horrell, I. and Bennett, J., 1981. Disruption of teat preferences and retardation of growth following crossfostering of 1-week-old pigs. Anim. Prod., 33: 99-106.

Horvat. J.R. and Kraemer, H.C., 1982. Behavioural changes during weaning in captive chimpanzees. Primates, 23: 488-499.

Huntingford, F.A., 1993. Behavioural mechanisms in evolutionary perspective. Trends Ecol. Evol., 8: 8184.

Jennions, M.D. and Macdonald, D.W., 1994. Cooperative breeding in mammals. Trends Ecol. Evol., 9: 89-93.

Jensen, P., 1980. An ethogram of social interaction patterns in group-housed dry sows. Appl. Anim. Ethol., 6: 341-350.

Jensen, P., 1986. Observations on the maternal behaviour of free-ranging domestic pigs. Appl. Anim. Behav. Sci., 16: 131-142.

Jones, G.P., 1983. The relationship between density and behaviour in juvenile Pseudolabrus celidotus (Pisces: Labtidae). Anim. Behav., 31: 729-735.

Keenleyside, M.H.A. and Yamamoto, F.T., 1962. Territorial behaviour of juvenile Atlantic salmon (Salmo salur L.). Behaviour, 19: 139-169.

Kelley, K.W., McGlone, J.J. and Gaskins, CT., 1980. Porcine aggression: measurement and effects of crowding and fasting. J. Anim. Sci., 50: 336-341.

Kennerley, M.J. and Lean, I.J., 1983. The effect of trough and floor feeding on behaviour and production in growing pigs. Anim. Prod., 36: 525, abstract.

King, R.H. and Williams, I.H., 1984. The effect of nutrition on the reproductive performance of first-litter sows. Anim. Prod., 38: 249-256.

König, B., 1993. Maternal investment of communally nursing female house mice (Mus musculus domesticus). Behav. Proc., 30: 61-74. 
König, B., 1994. Components of lifetime reproductive success in communally and solitarily nursing house mice-a laboratory study. Behav. Ecol. Sociobiol., 34: 275-283.

König, B. and Markl, H., 1987. Maternal care in house mice. I. The weaning strategy as a means for parental manipulation of offspring quality. Behav. Ecol. Sociobiol., 20: 1-9.

Krebs, J.R. and Davies, N.B. (Editors), 1991. Behavioural Ecology, an Evolutionary Approach, 3rd edn. Blackwell Scientific, Oxford.

Lank, D.B., Bousfield, M.A., Cooke, F. and Rockwell, R.F., 1991. Why do snow geese adopt eggs? Behav. Ecol., 2: 181-187.

Lazarus, J. and Inglis, I.R., 1986. Shared and unshared parental investment, parent-offspring conflict and brood size. Anim. Behav., 34: 1791-1804.

Leonard, M.L., Horn, A.G. and Eden, SF., 1988. Parent-offspring aggression in moorhens. Behav. Ecol. Sociobiol., 23: 265-270.

Martin, P., 1986. An experimental study of weaning in the domestic cat. Behaviour, 99: 221-249.

Martin, P.A. and Dziuk, P.J., 1977. Assessment of relative fertility of males (cockerels and boars) by competitive mating. J. Reprod. Fertil., 49: 323-329.

Marzluff, J.M. and Heimich, B., 1991. Foraging by common ravens in the presence and absence of territory holders: an experimental analysis of social foraging. Anim. Behav., 42: 755-770.

Mauget, R., 1981. Behavioural and reproductive strategies in wild forms of Sus scrofa (European wild boar and feral pigs). In: W. Sybesma (Editor), The Welfare of Pigs. Mattinus Nijhoff. The Hague, pp. 3-15.

McGlone, J.J., 1986. Influence of resources on pig aggression and dominance. Behav. Proc., 12: 135144.

Meese. G.B. and Ewbank, R., 1972. A note on instability of the dominance hierarchy and variations in level of aggression within groups of fattening pigs. Anim. Prod., 14: 359-362.

Mendl, M.T., Zanella, A.J. and Broom, D.M., 1992. Physiological and reproductive correlates of behavioural strategies in female domestic pigs. Anim. Behav., 44: 1107-1121.

Menella. J.A., Blumberg, M.S., McClintock, M.K. and Moltz, H., 1990. Inter-litter competition and commune nursing among Norway rats: advantages of birth synchrony. Behav. Bcol. Sociobiol., 27: 183190.

Mock, D.W., 1984. Infanticide, siblicide and avian nestling mortality. In: G. Hausfater and S.B. Hrdy (Editors), Infanticide: Comparative and Evolutionary Perspectives. Aldine, New York, pp. 3-30.

Mock, D.W., 1987. Siblicide, parent-offspring conflict, and unequal parental investment by egrets and herons. Behav. Ecol. Sociobiol., 20: 247-256.

Moore, A.S., Gonyou, H.W., Stookey, J.M. and McLaren, D.G., 1994. Effect of group composition and Pen size on behavior, productivity and immune response of growing pigs. Appl. Anim. Behav. Sci., 40: 13-30.

Nehring, A., 1981. One answer to the confinement pig problem. Int. J. Stud. Anim. Prob., 2: 256-259. 
Newberry, R.C. and Wood-Gush, D.G.M., 1985. The suckling behaviour of domestic pigs in a seminatural environment. Behaviour, 95: 11-25.

O'Gara, B.W., 1969. Unique aspects of reproduction in the female pronghom (Antilocapra americana Ord). Am. J. Anat., 125: 217-232.

Packard, J.M., Babbitt, K.J., Hannon, PG. and Grant, W.E., 1990. Infanticide in captive collared peccaries (Tayassu tajacu). Zoo. Biol., 9: 49-53.

Pajor, E.A., Fraser, D. and Kramer, D.L., 1994. Parent-offspring conflict in pigs. In: Proceedings of the 28th International Congress of the ISAE. National Institute of Animal Science, Foulum, Denmark.

Parker, G.A., 1974. Assessment strategy and the evolution of fighting behaviour. J. Theor. Biol., 47: 223243.

Parker, G.A. and MacNair, M.R., 1978. Models of parent-offspring conflict. I. Monogamy. Anim. Behav., 26: $97-110$.

Pusey, A.E. and Packer, C., 1994. Non-offspring nursing in social carnivores: minimizing the costs. Behav. Ecol., 5: 362-374.

Rantzer, D., 1993. Weaning of pigs in a sow-controlled and a conventional housing system for lactating sows. In: E. Collins and C. Boon (Editors), Livestock Environment IV. American Society of Agricultural Engineers, St. Joseph, pp. 468-475.

Rheingold, H., 1963. Maternal Behavior in Mammals. Wiley, London.

Rushen. J., 1987. A difference in weight reduces fighting when unacquainted newly weaned pigs first meet. Can. J. Anim. Sci., 67: 951-960.

Rushen, J., 1988. Assessment of fighting ability or simple habituation: what causes young pigs (Sus scrofa) to stop fighting? Aggress. Behav., 14: 155-167.

Rushen, J. and Pajor, E., 1987. Offence and defence in fights between young pigs (Sus scrofa). Aggress. Behav., 13: 329-346.

Sayler, A. and Salmon, M., 1969. Communal nursing in mice: influence of multiple mothers on the growth of the young. Science, 164: 1309-1310.

Sayler, A. and Salmon, M., 1971. An ethological analysis of communal nursing by the house mouse (Mus musculus). Behaviour, 40: 62-85.

Sherman, P.W., 1980. The limits of ground squirrel nepotism. In: G.W. Barlow and J. Silverberg (Editors), Sociobiology: Beyond Nature/Nurture? Westview Press, Boulder, pp. 505-544.

Slater, P.J.B., 1994. Kinship and altruism. In: P.J.B. Slater and T.R. Halliday (Editors), Behaviour and Evolution. Cambridge University Press, Cambridge, pp. 193-222.

Stacey, P.B. and Koenig, W.D., 1990. Cooperative Breeding in Birds: Long-term Studies of Ecology and Behaviour. Cambridge University Press, Cambridge.

Stamps, J.. Clark, A., Arrowood, P. and Kus, B., 1985. Parent-offspring conflict in budgerigars. Behaviour, 94: 1-40. 
Stephens, D.W. and Krebs, J.R. 1986. Foraging Theory. Princeton University Press, Princeton.

Sumption, L.J., Rempel, W.E. and Winters, L.M., 1959. Multiple sire mating in swine. I. General considerations. J. Hered., 50: 293-298.

Symoens, J. and van den Brande, M., 1969. Prevention and cure of aggressiveness in pigs using the sedative azaperone. Vet. Rec., 85: 6467.

Tinbergen, N., 1963. On aims and methods of ethology. Z. Tierpsychol., 20: 410-433.

Tindsley, E.C. and Lean, I.J., 1984. Effects of weight range at allocation on production and behaviour in fattening pig groups, Appl. Anim. Behav. Sci., 12: 79-92.

Trivers, R.L., 1972. Parental investment and sexual selection, In: T.H. Clutton-Brock and P.H. Harvey (Editors), Readings in Sociobiology. W.H. Freeman, San Francisco, pp. 52-95.

Trivers, R.L., 1974. Parent-offspring conflict. Am. Zool., 14: 249-264.

Trivers, R.L., 1985. Social Evolution. Benjamin/Cummins, Menlo Park.

Trumbo, S.T. and Wilson, D.S., 1993. Brood discrimination, nest mate discrimination, and determinants of social behaviour in facultatively quasisocial beetles (Nicrophorus spp.). Behav. Ecol., 4: 332-339.

Van der Lende, T. and de Jager, D., 1991. Death risk and preweaning growth rate of piglets in relation to the within-litter weight distribution at birth. Livest. Prod. Sci., 28: 73-84.

Warner, R.R., 1980. The coevolution of behavioral and life-history characteristics. In: G.W. Barlow and J. Silverberg (Editors), Sociobiology: Beyond Nature/Nurture? Westview Press, Boulder, pp. 151-188.

Williams, G.C., 1966. Adaptation and Natural Selection. A Critique of Some Current Evolutionary Thought, Princeton University Press, Princeton.

Wisenden, B.D. and Keenleyside, M.H.A., 1992. Intraspecific brood adoption in convict cichlids: a mutual benefit. Behav. Ecol. Sociobiol., 31: 263-269. 